\title{
VIDEOGRAFIA: BRASIL 500 ANOS?
}

bibliográfico

De acordo com o historiador Luís Felipe de Alencastro, comemorar nem sempre é festejar. Pensando nisso e em todas as possíveis comemorações que virão até o aniversário do Brasil e sabendo que muitos projetos sobre o tema estão sendo desenvolvidos, selecionei para este número da revista alguns documentários e outros filmes que podem ser trabalhados com os alunos e mesmo entre os professores.

Como o Descobrimento do Brasil não é um caso isolado do contexto dos descobrimentos e conquistas territoriais realizadas por Portugal e Espanha no século XV, pensei, para iniciar as leituras e as reflexões em torno dos 500 anos de Brasil, retomar a América Latina em seu conjunto de povos, culturas e diferentes tipos de dominação.

Meu intuito não será tanto o de propor formas de trabalho, mas trazer novas fontes de pesquisas, apresentando, em linhas gerais, o que cada documentário ou filme contém. Procurei, no entanto, organizá-los através de seqüências temáticas e, às vezes, temporais.

Nesta perspectiva, trouxe para este número os seguintes documentários e filmes: Ameríndia; 1492: a conquista do paraíso; República Guarani e Anchieta, José do Brasil.

\section{Ameríndia}

Roteiro/assessoria: D. Pedro Casaldáliga e José Oscar Beozzo

Narração: Luís Armando Queiroz

Direção de fotografia: Conrado Berning

Texto da Missa da Terra Sem Males

Trilha sonora: Marlui Miranda, Grupo Tarancón, Grupo Mashua

Produção: Verbo Divino

Ano: 1990

Duração: $35 \mathrm{~min}$

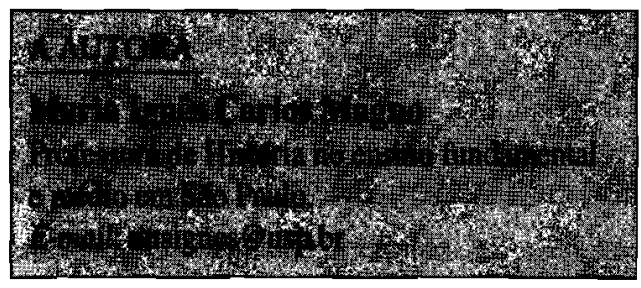


Ameríndia é um filme testemunho em torno do hábitat, da história e da evangelização da nossa América Indígena. Um filme para contemplação e reflexão. Um convite indeclinável na véspera do quinto centenário do mal chamado descobrimento e da ambígua evangelização. Branco não fala neste filme. Fala o índio, falam as flautas e a arte singular de Marlui Miranda e do grupo Tarancón. Ameríndia recolhe, em imagens inéditas ou redescobertas, a pureza dos povos do Xingu - os rituais dramáticos do Altiplano, o massacre das minas, a velha evangelização contestada e a reclamada nova evangelização.

\section{2: A conquista do paraíso (1492: Conquest of Paradise)}

Direção: Ridley Scott

Música: Vangelis

Roteiro: Roselyne Bosck

Fotografia: Adrian Biddle

Duração: $150 \mathrm{~min}$

Apontado como um dos melhores filmes do diretor Ridley Scott, narra a história do navegador genovês Cristóvão Colombo. Muito mais do que contar os fatos marcantes do Descobrimento da América, o diretor mostra Colombo como alguém que está realizando algo grandioso, cumprindo um ritual de herói. Tanto seu idealismo frente à intolerância de sua época, quanto a epopéia de sua chegada ao Novo Mundo e sua convivência com os índios são apresentados de maneira precisa.

\section{República Guarani}

Direção: Sílvio Back

Produção: SIV Vídeo

Ano: 1982

Duração: $100 \mathrm{~min}$

Documentário de Sílvio Back discute o projeto social criado por jesuítas entre 1610 e 1767, envolvendo 500 mil índios em 50 cidades indígenas, compreendendo o Uruguai, o Paraguai e o Paraná. Segundo o diretor, o filme põe sob suspeita todo e qualquer tipo de evangelização do indígena ou dominação do indígena, no passado e no presente.

\section{Anchieta, José do Brasil}

Direção: Paulo César Saracceni

Produção: Sérgio G. Saracceni

Argumento: Marcos Konder Reis

Ano: 1978

Duração: $140 \mathrm{~min}$ 
Filme de Paulo César Saracceni, de 1978, é um filme de ritmo lento: um dos poucos filmes sinceramente religiosos produzidos no Brasil. Ele mostra a atuação de José de Anchieta no Brasil. Jesuíta que chegou ao país em 1553, e em apenas três meses aprendeu a língua tupi, os hábitos e costumes dos índios. Com a chegada dos franceses, Anchieta interrompe seu trabalho junto aos índios para negociar a paz.

$O$ índio, a conquista, a catequização como forma de colonização compõem o eixo norteador do filme. As imagens, os textos, as músicas, a relação dos povos com a terra, os corpos, as artes, os cultos, as visões da Virgem e dos projetos de evangelização dos povos, as falas das lideranças indígenas, as inúmeras visões de paraísos ou de infernos Potosis provocam o desejo de conhecer, de discutir, de redescobrir américas, brasis e de compreender a frase do historiador ou do líder indígena, que ao defender um deus visível reafirma o quão sagrada é a terra.

Para orientar as discussões com os alunos os professores podem ler, antecipadamente, dois textos que trarão novas indicações para a reflexão sobre o tema, bem como ajudarão a desenvolver o trabalho sobre os 500 anos de Descobrimento nas aulas de Português, seja na orientação para as aulas de Redação ou de Literatura. Os textos propostos são: Terra à vista. Discurso do confronto: velho e novo mundo', e Dialética da Colonização, de Alfredo Bosi ${ }^{2}$. Do livro de Eni Orlandi, proponho que se trabalhe a Introdução. Trata-se de um belíssimo texto, de fácil leitura, que permite uma profunda reflexão sobre os usos de língua e a formação dos estereótipos. O texto discute como o discurso dos descobridores passa a dar existência aos povos da terra, desprezando sua cultura e organização. Do livro de Alfredo Bosi sugiro que se dê prioridade para a leitura dos itens 1, 2 e 3 . Aí serão encontradas referências importantes para o conceito de cultura e para a reflexão sobre a aculturação dos nativos, levada a cabo pelos jesuítas, principalmente, através de Pe. José de Anchieta. É o início da literatura do Novo Continente.

Acredito que essas referências, trabalhadas em conjunto, podem ajudar os professores a desenvolverem diversos projetos, propiciando aos alunos informações importantes para um conhecimento mais amplo sobre nossas origens. 